\title{
PERANCANGAN SISTEM INFORMASI ELEKTRONIK LOG BOOK PENANGKAPAN IKAN BERBASIS WEB
}

\author{
DESIGN OF INFORMATION SYSTEM FOR ELECTRONIC FISHING LOG BOOK WEB-BASED
}

\author{
Hadhi Nugroho, Adi Darmawan, dan Agus Sufyan \\ Pusat Pengkajian dan Perekayasaan Teknologi Kelautan dan Perikanan, Jl. Pasir Putih I Ancol Timur, Jakarta \\ Email: hadhinugroho@gmail.com
}

Diterima tanggal: 24 Oktober 2016, diterima setelah perbaikan: 27 Januari 2017, disetujui tanggal: 30 Januari 2017

\begin{abstract}
ABSTRAK
Pusat Pengkajian dan Perekayasaan Teknologi Kelautan dan Perikanan (P3TKP) - Kementerian Kelautan dan Perikanan (KKP) telah mengembangkan teknologi elektronik log book penangkapan ikan berbasis GPRS. Elektronik log book merupakan perangkat keras yang memiliki fungsi utama untuk input data tangkapan ikan secara elektronik. Untuk menampilkan data elektronik log book menjadi informasi statistik secara real time, diperlukan sebuah sistem informasi berbasis web. Tahapan perancangan sistem informasi elektronik log book penangkapan ikan berbasis web terdiri dari identifikasi kebutuhan sistem, perancangan perangkat lunak, dan implementasi. Perancangan desain sistem database elektronik log book menggunakan MySQL. Desain sistem database tersebut berisi Conceptual Data Model (CDM) dan Physical Data Model (PDM). Untuk menggambarkan interaksi pengguna dengan sistem informasi elektronik log book dapat dilihat pada Data Flow Diagram (DFD). DFD pada perancangan sistem informasi elektronik log book terdiri dari DFD level-0, DFD level-1, dan DFD level-2. Modul-modul pada sistem informasi elektronik log book terdiri dari modul autentifikasi, modul data tangkapan, modul informasi harga ikan, dan modul informasi cuaca. Aplikasi kemudian diimplementasikan di domain www.p3tkp-elogbook.net. Sistem informasi elektronik log book penangkapan ikan berbasis web yang diaplikasikan ini dapat memberikan informasi secara cepat dan tepat tentang data penangkapan ikan, informasi harga ikan, dan informasi cuaca perairan, dengan kerahasiaan data yang terjamin.
\end{abstract}

Kata kunci: sistem informasi, web, elektronik log book, pengguna

\begin{abstract}
Research and Development Center of Marine and Fisheries Technology (P3TKP) - Ministry of Maritime Affairs and Fisheries (KKP) has developed an electronic fishing log book technology based GPRS. Electronic log book is a hardware device that has a primary function for input catches data electronically. To display the electronic log book data into statistical information in real time, needed a web-based information system. The design stage of electronic fishing log book information system web based consists of system requirements identification, software design, and implementation. The design of database system an electronic log book using MySQL. The design of the database system contains a Conceptual Data Model (CDM) and Physical Data Model (PDM). To describe the user interaction with the electronic log book information system can be seen in the Data Flow Diagrams (DFD). DFD in the design of an electronic log book information system consists of DFD level-0, DFD level-1 and DFD level-2. The modules in the electronic log book information system consist of the authentication module, the data module catches, the fish price information module, and the module weather information. The application is then implemented in the domain www.p3tkp-elogbook.net. The fishing electronic log book information system applied can provide information quickly and accurately about the fishing data, the fish price information, and the marine weather information, with the data confidentiality is assured.
\end{abstract}

Keywords: information system, web, electronic log book, user 


\section{PENDAHULUAN}

Pusat Pengkajian dan Perekayasaan Teknologi Kelautan dan Perikanan (P3TKP) - Kementerian Kelautan dan Perikanan (KKP) telah mengembangkan teknologi elektronik $\log$ book penangkapan ikan berbasis GPRS. Elektronik $\log$ book penangkapan ikan, yang kemudian cukup disebut elektronik log book merupakan perangkat keras yang memiliki fungsi utama untuk input data tangkapan ikan secara elektronik (Marzuki dan Nugroho, 2013). Perangkat keras elektronik log book yang dihasilkan oleh P3TKP tahun 2013 dapat dilihat pada Gambar 1.

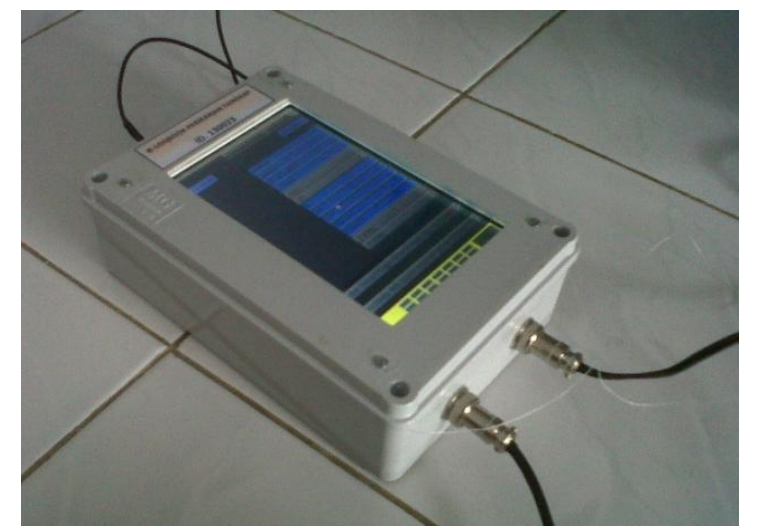

Gambar 1. Perangkat keras elektronik log book P3TKP tahun 2013

(The hardware of P3TKP electronic log book year 2013)

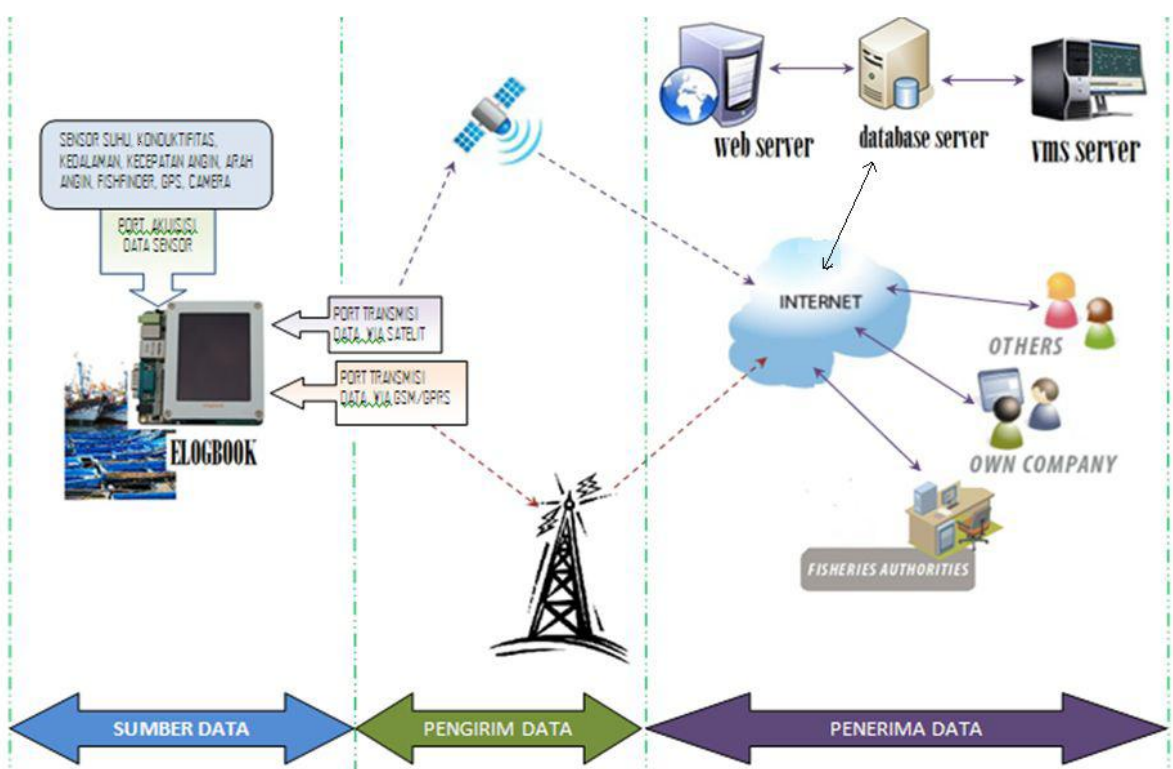

Gambar 2. Prinsip kerja elektronik log book penangkapan ikan (Sumber: Marzuki, 2010)

(Work methods of fishery electronic log book)
Perangkat keras elektronik log book tersebut menggunakan layar sentuh untuk memasukkan dan menampilkan data. Fitur / format data pada elektronik $\log$ book tersebut sesuai dengan Peraturan Menteri Kelautan dan Perikanan No. PER. 18/MEN/2010 tentang Log Book Penangkapan Ikan (Nugroho dan Sufyan, 2014), sehingga data yang harus dimasukkan oleh nelayan ke dalam elektronik log book adalah data kapal perikanan, data alat penangkapan ikan, data operasi penangkapan ikan, dan data ikan hasil tangkapan (Republik Indonesia, 2010). Selain data penangkapan ikan, alat ini juga memiliki fitur / menu aplikasi lainnya yang mendukung aktivitas penangkapan ikan, yaitu rekam jejak kapal (VMS), informasi cuaca, informasi koordinat Peta Prakiraan Daerah Penangkapan Ikan (PPDPI), informasi harga ikan, informasi suhu permukaan laut, dan informasi kondisi darurat / emergensi (Nugroho dan Sufyan, 2014). Prinsip kerja elektronik log book dapat dilihat pada Gambar 2.

Secara umum, prinsip kerja elektronik log book, yaitu di atas kapal, nelayan atau kapten kapal mengisi data tangkapan ikan ke dalam elektronik log book. Selain data tangkapan ikan, alat ini juga dilengkapi dengan fitur rekam jejak kapal. Data rekam jejak kapal ini dapat diatur otomatis setiap jam, sehingga dapat diketahui pergerakan kapal dari berangkat hingga mendarat kembali di pelabuhan. Semua data tersebut akan dikirim ke web server melalui jaringan GPRS (General 
Packet Radio Service). Jika tidak terdapat sinyal GPRS, maka data tersebut akan disimpan di perekam data (data logger). Setelah menerima kembali sinyal GPRS, maka semua data yang tersimpan di perekam data akan terkirim secara otomatis ke web server (Marzuki dan Nugroho, 2013).

Untuk menampilkan data elektronik log book menjadi informasi statistik secara real time, diperlukan sebuah sistem informasi berbasis web. Sistem informasi adalah sebuah sistem komputer yang bertugas mengolah data untuk menghasilkan informasi, di mana pada sistem informasi ini dilengkapi dengan alat komunikasi yang dipergunakan untuk saling tukar informasi atau data dengan peralatan yang lain. Dengan demikian, sistem informasi berbasis web adalah sebuah sistem informasi yang menggunakan teknologi web atau internet untuk memberikan informasi dan layanan kepada pengguna atau sistem informasi lain / aplikasi lain. Sebuah sistem informasi berbasis web biasanya terdiri dari satu atau lebih aplikasi web yang masing-masing komponen mempunyai fungsi tertentu. Masingmasing komponen tersebut saling mendukung satu dengan yang lainnya guna mencapai fungsi sistem informasi berbasis web secara umum (Setiawan, 2013). Sistem informasi elektronik log book sebagai suatu aplikasi berbasis web sudah pernah dibuat pada tahun 2011 oleh P3TKP. Namun demikian, aplikasi berbasis web tersebut belum dilengkapi autentifikasi pengguna sebagai bagian dari keamanan aplikasi dan hak akses bagi pengguna. Pengguna di sini adalah pihak-pihak yang berkepentingan terhadap data elektronik $\log$ book tersebut, yaitu pemilik kapal, pelabuhan perikanan, dan otoritas perikanan (Kementerian Kelautan dan Perikanan / KKP). Aplikasi berbasis web tersebut hanya berisi tentang fitur tabel periodik untuk melihat data perjalanan kapal dan tabel tangkapan untuk melihat hasil tangkapan ikan. Informasi-informasi penting yang dibutuhkan nelayan berkaitan dengan cuaca, harga ikan dan peta perkiraan daerah penangkapan ikan belum tersaji dalam sistem informasi elektronik log book sebagai suatu aplikasi berbasis web pada tahun 2011 tersebut.

Ada beberapa syarat untuk dapat membentuk sistem informasi berbasis web. Syarat pertama adalah adanya sebuah web server yang mampu untuk mendukung sistem informasi tersebut. Saat ini web server yang paling terkenal adalah Apache Web Server. Hal lain yang menjadi syarat mutlak adalah perangkat lunak pemrograman web. Harus ada sebuah bahasa pemrograman web sebagai pendamping HTML. Salah satu yang terkenal adalah PHP. Hal penting lainnnya adalah database yang handal untuk menyimpan dan memanajemen data. Database yang dipergunakan harus mampu menangani berjuta-juta data dan dapat diakses dengan sangat cepat. Salah satu database yang direkomendasikan adalah Oracle karena kemampuannya sangat handal. Atau bisa pula menggunakan MySQL untuk database yang tidak terlalu besar (Setiawan, 2013).

Data log book penangkapan ikan merupakan data yang bersifat rahasia. Kerahasiaan tersebut dijamin oleh pemerintah melalui undang-undang perikanan (Republik Indonesia, 2009). Oleh karena itu, dalam perancangan sistem informasi elektronik log book penangkapan ikan berbasis web ini, situs web hanya bisa diakses oleh pihak tertentu saja. Untuk itu pada perancangan sistem informasi, akan ditambahkan modul autentifikasi berupa form login yang berisi kolom-kolom untuk input username dan password. Pengunjung situs harus mengisi kolom-kolom input tersebut dengan tepat untuk dapat mengakses informasi dari elektronik log book.

Tujuan penelitian ini adalah untuk mengembangkan sistem informasi elektronik $\log$ book penangkapan ikan berbasis web yang diharapkan dapat memudahkan pihak berkepentingan memperoleh data penangkapan ikan sehingga dapat digunakan untuk mengelola sumber daya perikanan yang berkelanjutan. Ruang lingkup atau pembatasan masalah pada perancangan sistem informasi ini adalah sebagai berikut:

- Modul yang akan dikembangkan hanya mencakup fitur penerimaan data dan menampilkan data

- Autentifikasi untuk menambahkan data sistem informasi akan menggunakan autentifikasi lokal

- Data yang ditampilkan untuk umum tidak disediakan, semuanya diharuskan melewati proses autentifikasi. 
BAHAN DAN METODE

Penelitian ini menggunakan metode "deskriptif", dengan waktu pelaksanaan penelitian selama 10 bulan (Februari-November 2013). Langkah / proses perancangan sistem informasi elektronik log book penangkapan ikan berbasis web terdiri dari:

- Identifikasi kebutuhan sistem

Perancangan modul-modul yang ada di dalam sistem informasi elektronik log book dilakukan berdasarkan identifikasi kebutuhan. Kegiatan ini dilaksanakan selama 3 bulan (FebruariApril 2013).

- Perancangan perangkat lunak

Rancangan perangkat lunak elektronik log book dituangkan menjadi sebuah aplikasi menggunakan perangkat-perangkat berikut ini:

- Untuk portal informasi elektronik log book menggunakan framework pemrograman CodeIgniter yang berbasis PHP

- Untuk socket server menggunakan PHP murni dengan bantuan pustaka ADODB untuk koneksi ke database-nya.

- MySQL untuk implementasi sistem database

- Apache Web Server

- jQuery

Pengembangan elektronik log book dilakukan dengan menggunakan perangkat komputer (PC) dengan sistem operasi LINUX CentOS 6.3. untuk komputer server. Webserver Apache v2.2.15, PHP Version 5.3.3 sebagai bahasa pemrograman untuk membangun aplikasi berbasis web dan menggunakan MySQL5.1.66 sebagai database aplikasi. Kegiatan perancangan perangkat lunak ini dilakukan selama 4 bulan (Mei-Agustus 2013).

- Implementasi (Coding)

Aplikasi ini akan diimplementasikan di domain www.p3tkp-elogbook.net. Proses ujicoba hingga implementasi dilakukan selama 3 bulan (September-November 2013).

\section{HASIL DAN PEMBAHASAN}

\subsection{Identifikasi Kebutuhan Sistem}

Tahap awal perancangan sistem informasi elektronik log book penangkapan ikan adalah identifikasi kebutuhan sistem. Perancangan

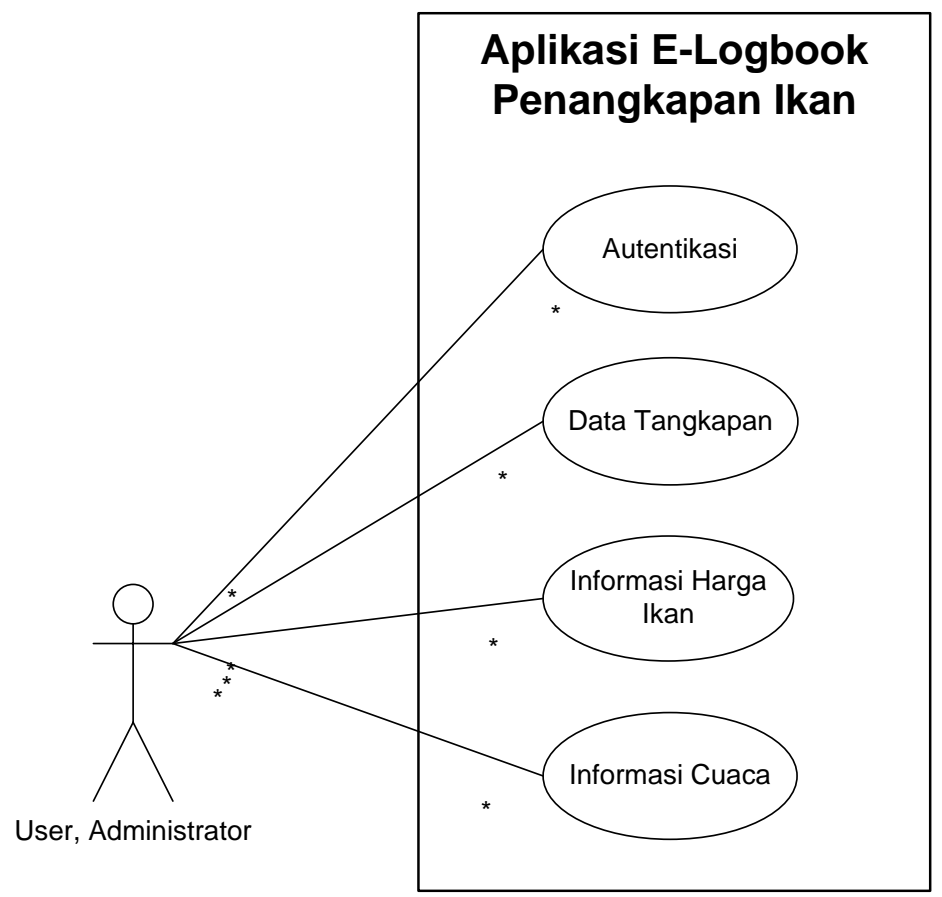

Gambar 3. Rancangan modul pada aplikasi elektronik log book penangkapan ikan (Module design at fishery electronic log book application) 
modul-modul yang ada di dalam sistem informasi elektronik log book dilakukan berdasarkan identifikasi kebutuhan. Rancangan modul pada sistem informasi elektronik log book dapat dilihat pada Gambar 3.

Modul-modul pada sistem informasi elektronik log book dapat dikelompokkan sebagai berikut:

1. Modul pemeriksaan hak akses pengguna, terdiri dari:

- Modul autentifikasi

2. Modul pengelolaan data sistem, terdiri dari:

- Modul data tangkapan

- Modul informasi harga ikan
- Modul informasi cuaca

3.2. Perancangan Sistem Database Elektrronik Log Book

Desain sistem database elektronik log book berisi Conceptual Data Model (CDM) dan Physical Data Model (PDM). CDM merupakan perancangan tabel yang berelasi untuk mengintegrasikan akses data dan model-model keputusan sebelum di-generate dalam suatu DBMS (Database Management System). Kemampuan ini dapat dilakukan dengan menambahkan model-model sistem informasi ke dalam suatu sistem yang menggunakan database

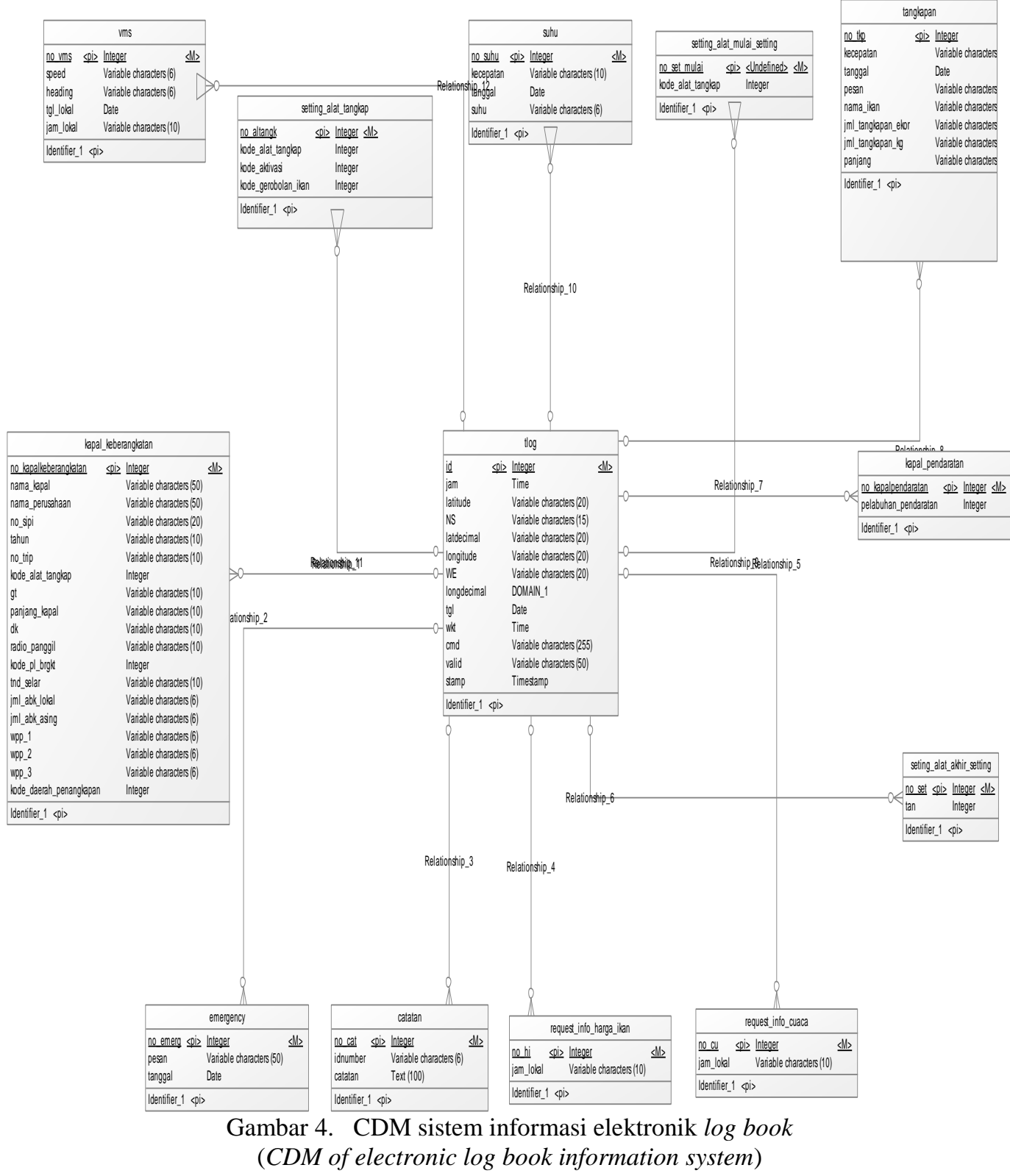

Perancangan Sistem Informasi Elektronik Log Book Penangkapan Ikan Berbasis Web - Hadhi Nugroho, Adi Darmawan, dan Agus Sufyan 
sebagai mekanisme integrasi dan komunikasi di antara model-model (Kuswardayan, 2004). CDM pada sistem informasi elektronik log book dapat dilihat pada Gambar 4.

PDM merupakan hasil proses generate pada proses CDM (Kuswardayan, 2004). PDM pada sistem informasi elektronik log book dapat dilihat pada Gambar 5.

Dari Gambar 4 dapat diketahui model hubungan antar tabel dalam suatu database. tlog dalam database elektronik log book merupakan tabel untuk menampung data dari alat elektronik $\log$ book. tlog merupakan tabel master atau tabel utama yang memiliki primary key berupa "id". Id tersebut menjadi penghubung antar tabel dalam suatu relationship one to many tabel-tabel dalam database elektronik log book. Gambar 5 merupakan model hubungan antar tabel secara fisik, yang menggambarkan id dari tabel tlog sudah terdaftar / terdistribusi ke seluruh tabel database. Bentuk Physical Data Model (PDM) merupakan model database yang diimplementasikan dalam bentuk database elektronik $\log$ book. Tabel-tabel tersebut dapat dilihat pada Tabel 1.

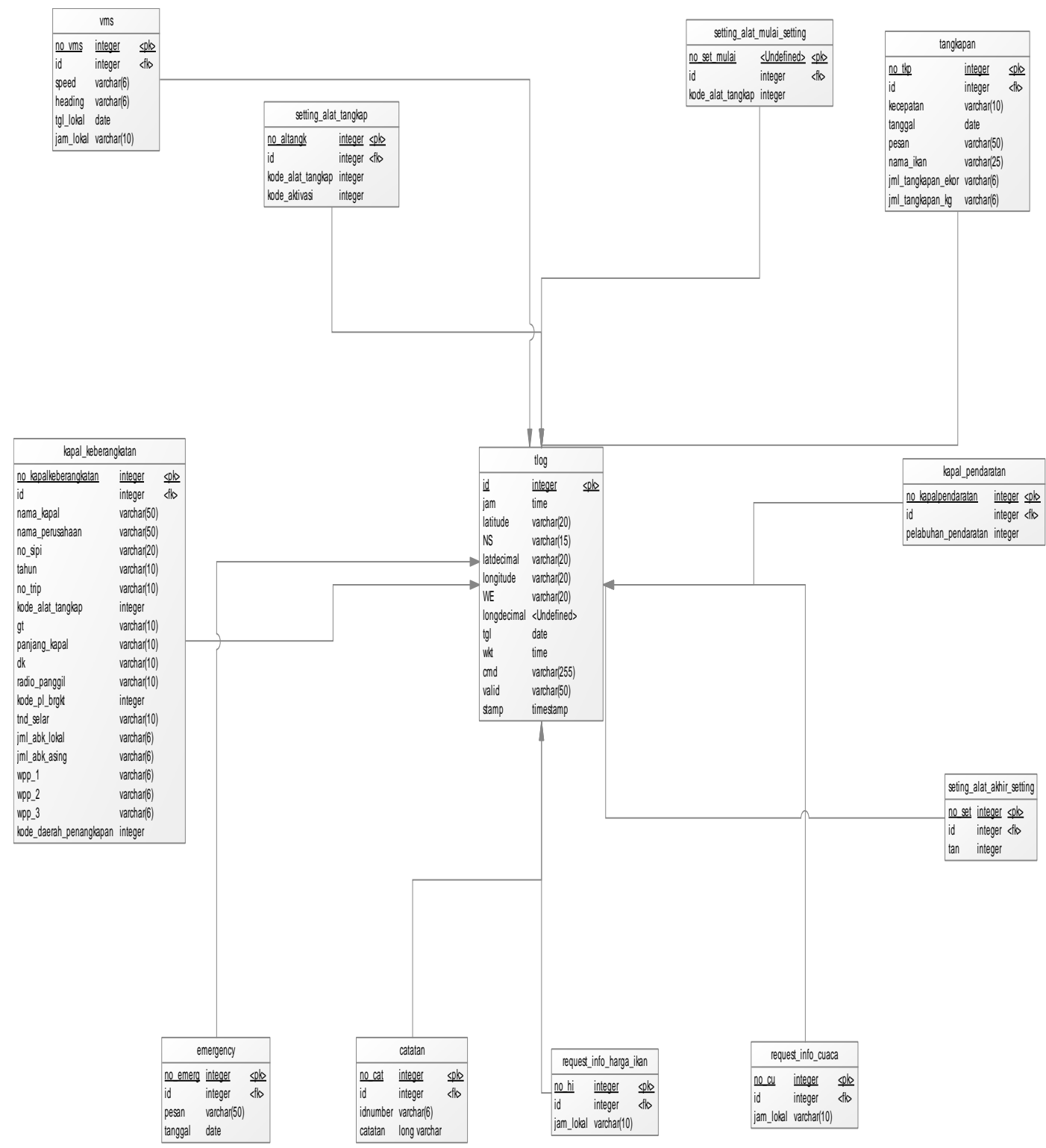

Gambar 5. PDM sistem informasi elektronik log book (PDM of electronic log book information system) 
Tabel 1. Tabel-tabel dalam database sistem informasi elektronik log book

\begin{tabular}{|l|l|l|}
\hline $\begin{array}{c}\text { Kode } \\
\text { Tabel }\end{array}$ & \multicolumn{1}{|c|}{ Nama Tabel } & \multicolumn{1}{c|}{ Keterangan } \\
\hline$[\mathrm{T}-01]$ & Tautentifikasi & Tabel untuk menampung data pengguna system \\
\hline$[\mathrm{T}-02]$ & Tlog & Tabel untuk menampung raw data kiriman dari alat \\
\hline$[\mathrm{T}-03]$ & kapal_keberangkatan & Tabel untuk menampung data log Kapal Keberangkatan \\
\hline$[\mathrm{T}-04]$ & seting_alat_tangkap & Tabel untuk menampung data setting alat tangkap suatu alat \\
\hline$[\mathrm{T}-05]$ & seting_alat_mulai_seting & Tabel untuk menampung data alat ketika mulai di-setting \\
\hline$[\mathrm{T}-06]$ & seting_alat_akhir_seting & Tabel untuk menampung data alat ketika selesai di-setting \\
\hline$[\mathrm{T}-07]$ & Tangkapan & Tabel unutk menampung data tangkapan suatu alat \\
\hline$[\mathrm{T}-08]$ & request_info_cuaca & Tabel untuk menampung data info cuaca \\
\hline$[\mathrm{T}-09]$ & request_info_harga_ikan & Tabel untuk menampung data harga ikan \\
\hline$[\mathrm{T}-10]$ & Suhu & Tabel untuk menampung data laporan suhu dari alat \\
\hline$[\mathrm{T}-11]$ & Vms & Tabel untuk menampung data vms \\
\hline$[\mathrm{T}-12]$ & kapal_pendaratan & Tabel untuk menampung data pendaratan suatu kapal \\
\hline$[\mathrm{T}-13]$ & Catatan & Tabel untuk menampung data catatan dari alat \\
\hline$[\mathrm{T}-14]$ & Ikan & $\begin{array}{l}\text { Tabel untuk menampung data master ikan yang dijadikan referensi } \\
\text { untuk pencatatan data tangkapan ikan }\end{array}$ \\
\hline$[\mathrm{T}-15]$ & emergency_note & Tabel untuk menampung data master jenis catatan \\
\hline
\end{tabular}

Untuk menggambarkan interaksi pengguna dengan sistem informasi elektronik log book, maka bisa dilihat dalam data flow diagram (DFD). DFD merupakan diagram aliran data yang merupakan model dari sistem untuk menggambarkan pembagian sistem ke dalam modul-modul yang lebih kecil. DFD digunakan untuk mengetahui jalannya sistem yang dibuat dengan menunjukkan interaksi antara pengguna dan prosesnya. DFD juga menunjukkan data yang diproses oleh sistem disimpan dalam bentuk tabel dalam database (Pohan, 1997).
DFD level-0 atau sering disebut diagram konteks merupakan level tertinggi dari DFD (Exa, 2015). DFD level-0 menggambarkan satu lingkaran besar yang dapat mewakili seluruh proses yang terdapat di dalam suatu sistem (Pratama, 2013). DFD level-0 pada sistem informasi elektronik log book dapat dilihat pada Gambar 6 .

DFD level-1 merupakan aliran data yang lebih spesifik dalam memberikan gambaran sistem serta merupakan penjelasan dari DFD level-0 (Soejarwo dan Darmawan, 2011). DFD level-1 pada sistem informasi elektronik log book dapat

Hak Akses

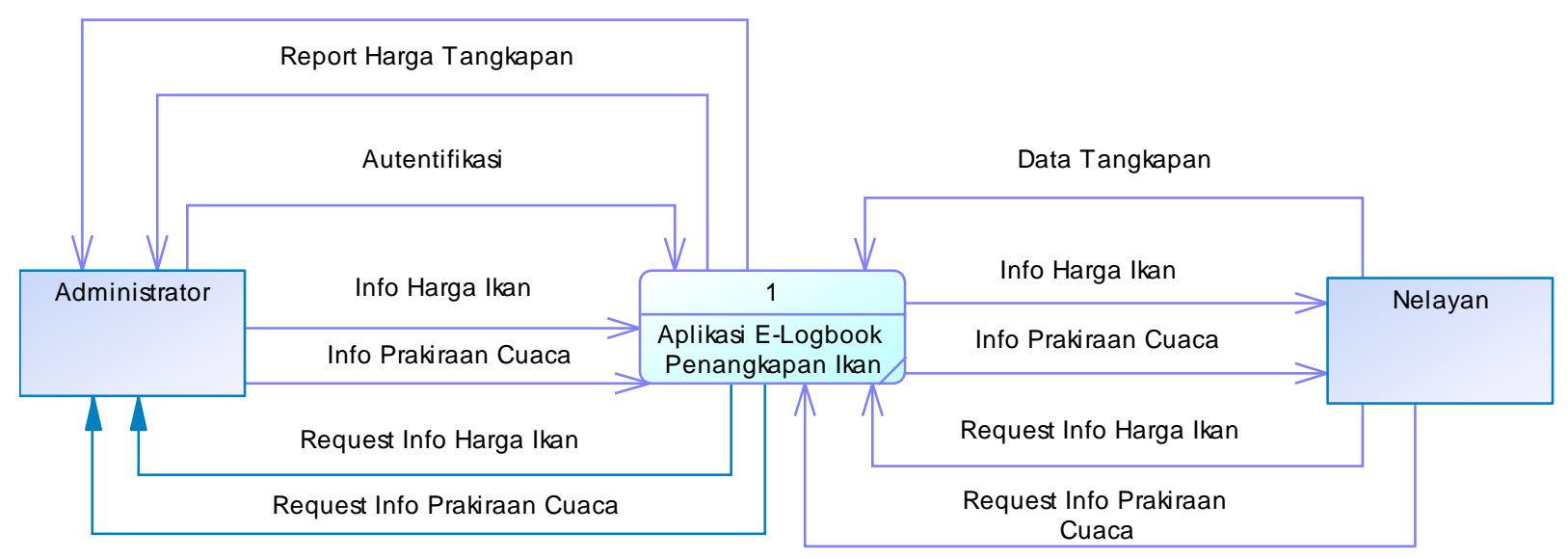

Gambar 6. DFD level-0 sistem informasi elektronik log book

(DFD level-0 of electronic log book information system) 
dilihat pada Gambar 7.

Proses permintaan informasi harga ikan dan informasi cuaca pada DFD level-1 dapat dijabarkan lebih rinci pada DFD level-2. DFD level-2 pada sistem informasi elektronik log book dapat dilihat pada Gambar 8.

Penjelasan proses pada DFD level-2 adalah sebagai berikut:

1. Proses 1 (login), merupakan proses yang harus dilakukan setiap pengguna untuk bisa menjalankan sistem. Proses login membutuhkan input berupa username dan password yang akan dicek oleh sistem apakah username dan password yang dimasukkan sama dengan yang ada dalam tabel login pada suatu database. Proses login menghasilkan keluaran berupa hak akses masing-masing pengguna sistem dengan indikatornya berupa user status (Soejarwo dan Darmawan, 2011).

2. Proses 2 (pengolahan data tangkapan ikan), merupakan proses pengolahan data tangkapan ikan yang berasal dari data yang diinput oleh nelayan ke dalam perangkat keras elektronik log book.
3. Proses 3 (permintaan informasi harga ikan), merupakan proses untuk mengolah permintaan informasi harga ikan oleh nelayan. Saat nelayan meminta informasi harga ikan melalui perangkat keras elektronik log book, maka permintaan tersebut akan masuk ke sistem. Sistem akan mengambil data harga ikan dari tabel harga ikan, di mana data pada tabel harga ikan tersebut berasal dari Pusat Informasi Pelabuhan Perikanan (www.pipp.djpt.kkp.go.id). Proses ini menghasilkan keluaran berupa informasi harga ikan.

4. Proses 4 (permintaan informasi cuaca), merupakan proses untuk mengolah permintaan informasi cuaca perairan oleh nelayan. Saat nelayan meminta informasi cuaca perairan melalui perangkat keras elektronik log book, maka permintaan tersebut akan masuk ke sistem. Sistem akan mengambil data cuaca dari tabel, di mana data pada tabel cuaca tersebut berasal dari Badan Meteorologi, Klimatologi, dan Geofisika (www.bmkg.go.id). Proses ini menghasilkan keluaran berupa informasi cuaca perairan.

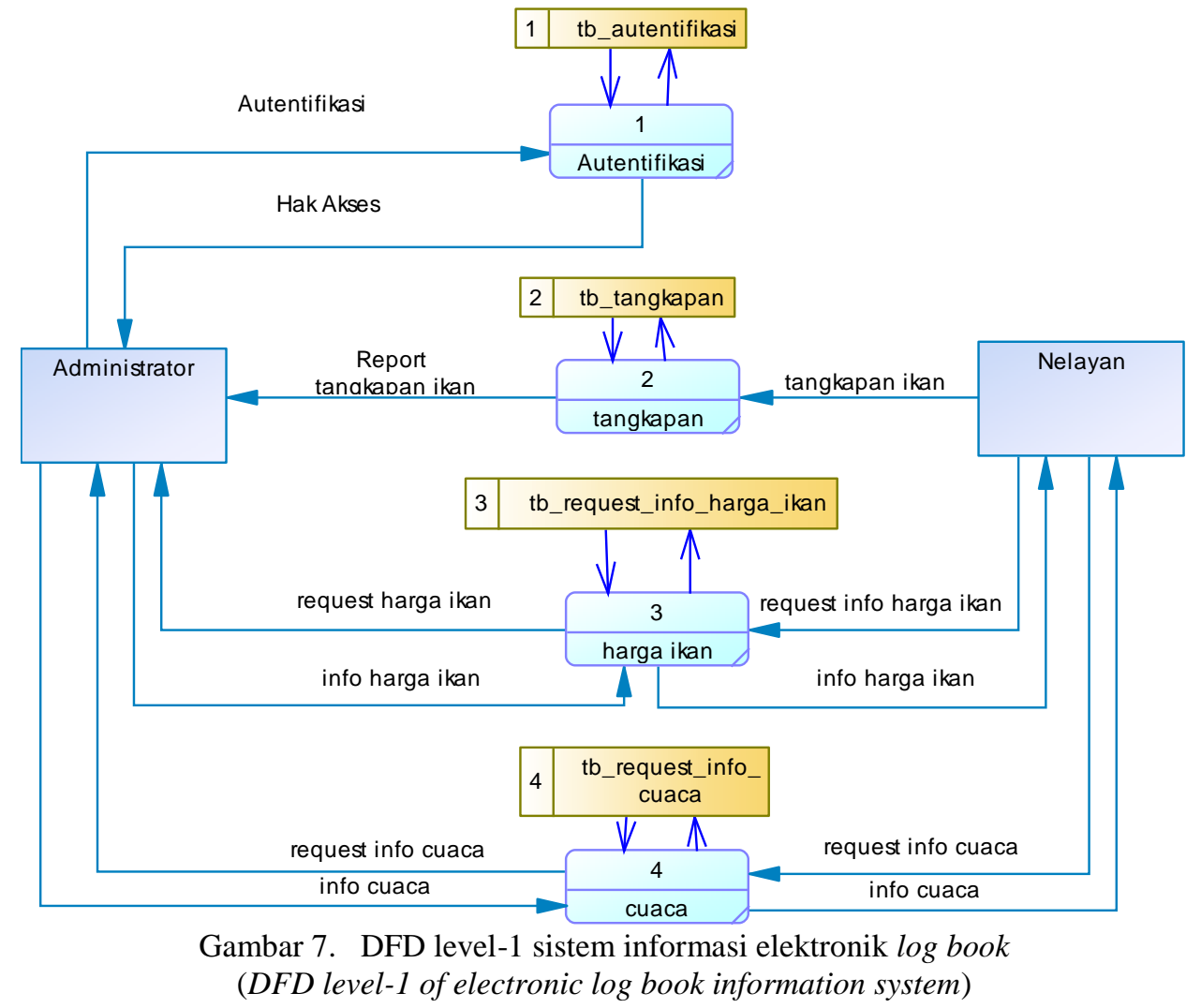




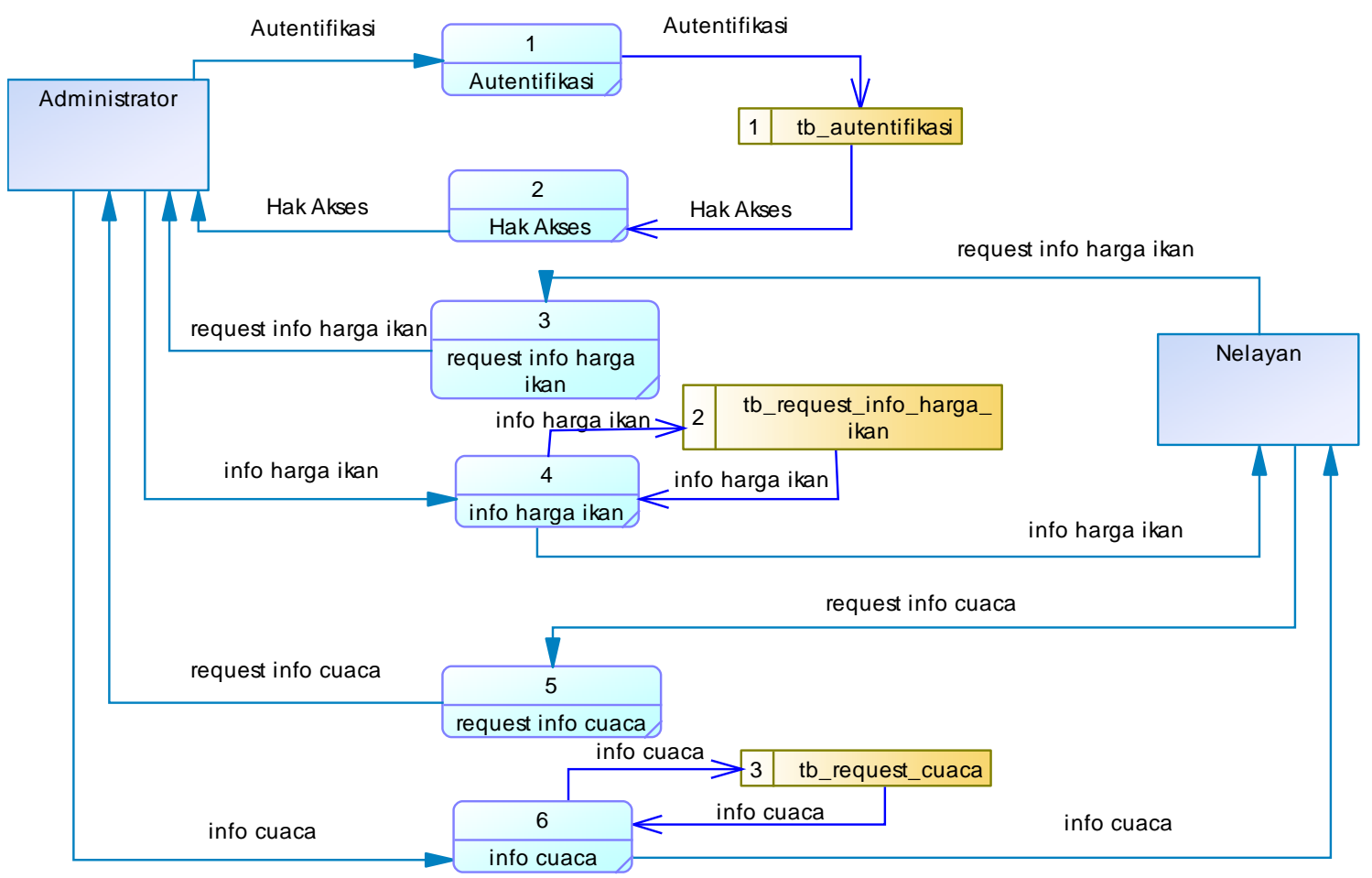

Gambar 8. DFD level-2 sistem informasi elektronik log book (DFD level-2 of electronic log book information system)

\subsection{Implementasi Sistem}

\section{Modul Autentikasi}

Modul ini memiliki fungsi untuk autentifikasi pengguna aplikasi. Sistem akan menampilkan form login yang berisi kolom-kolom untuk input username dan password serta tombol submit login. Pengguna situs mengisi kolom-kolom input dengan data yang diminta lalu meng-klik tombol login. Sistem kemudian memeriksa apakah username yang diinputkan terdaftar di database. Jika terdaftar maka akan menuju ke langkah selanjutnya, jika tidak terdaftar maka sistem akan menampilkan pesan kesalahan ke pengguna dan menghentikan proses autentifikasi. Sistem menyimpan informasi identitas pengguna, identitas unit kerja, dan hak akses pengguna ke dalam session. Sistem menampilkan menu logout untuk keluar dari aplikasi. Jika pengguna keluar dari aplikasi dengan meng-klik menu logout,

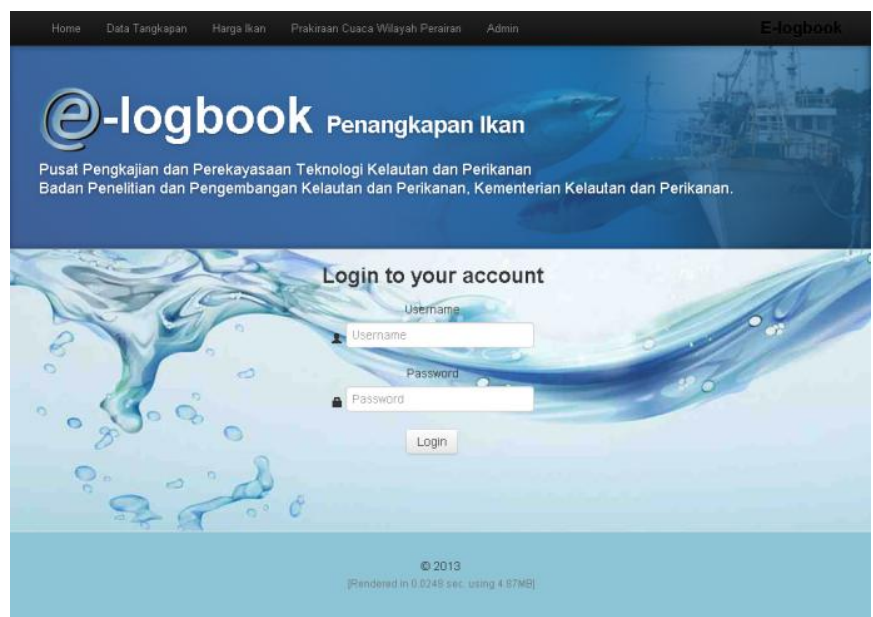

Gambar 9. Halaman login situs web elektronik log book (Login page at electronic log book website) 
maka sistem akan menghapus informasi pengguna yang tersimpan di session sehingga pengguna tidak bisa mengakses halaman-halaman yang diperuntukkan bagi pengguna yang login ke sistem.

\section{Modul Data Tangkapan}

Modul ini memiliki fungsi untuk menampilkan data tangkapan dengan mengakses tab VMS, Tangkapan, Emergency, Seting Alat, Suhu, Keberangkatan, Pendaratan, Catatan, Filter Data dan Lihat Map. Pengguna aplikasi menampilkan Data Tangkapan berdasarkan kebutuhan data dengan mengakses tab-tab yang ada (VMS, Tangkapan, Emergency, Seting Alat, Suhu, Keberangkatan, pendaratan, Pencatatan). Datadata yang ditampilkan dapat difilter sesuai dengan kebutuhan. Filter data tersebut berdasarkan ID number (dengan meng-klik link ID Number secara langsung) atau bisa juga diakses dengan memasukan ID number, tanggal awal dan tanggal akhir pada input filter. ID number di sini adalah nomor identitas perangkat keras elektronik log book, yang juga mewakili nomor identitas kapal perikanan (Marzuki dan Nugroho, 2013). Apabila pengguna ingin me-reset dan menampilkan data semula, dapat dilakukan dengan meng-klik tombol Reset Data. Pengguna dapat melihat letak ID number pada peta berdasarkan koordinat lintang dan bujur, dengan meng-klik link LIHAT MAP.

Gambar 10 menunjukkan tab menu VMS pada modul data tangkapan. Data yang ditampilkan pada tab menu ini berasal dari perangkat keras elektronik log book. Elektronik log book diprogram untuk mencatat data rekam jejak kapal (vessel tracking) setiap 30 menit sekali secara

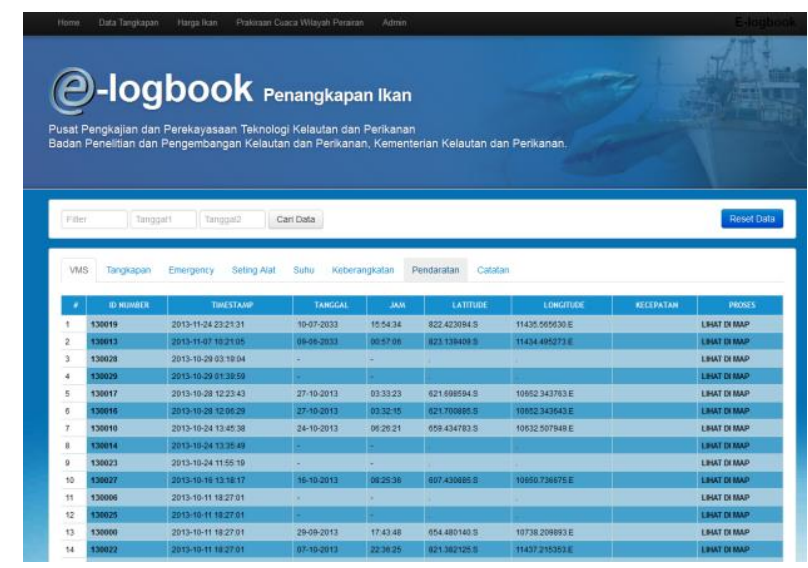

Gambar 10. Tab menu VMS pada Modul Data

Tangkapan

(Menu tab VMS at Catch Data Module) otomatis. Data rekam jejak kapal tersebut berisikan waktu, posisi koordinat, kecepatan kapal, dan arah kapal / heading (Nugroho et. al., 2013).

Gambar 11 menunjukkan tab menu Tangkapan pada modul data tangkapan. Data yang ditampilkan pada tab menu ini berasal dari pengisian data tangkapan ikan oleh nelayan pada alat elektronik log book. Data tersebut berisi waktu, posisi koordinat, nama ikan, dan jumlah ikan (dalam kilogram dan ekor).

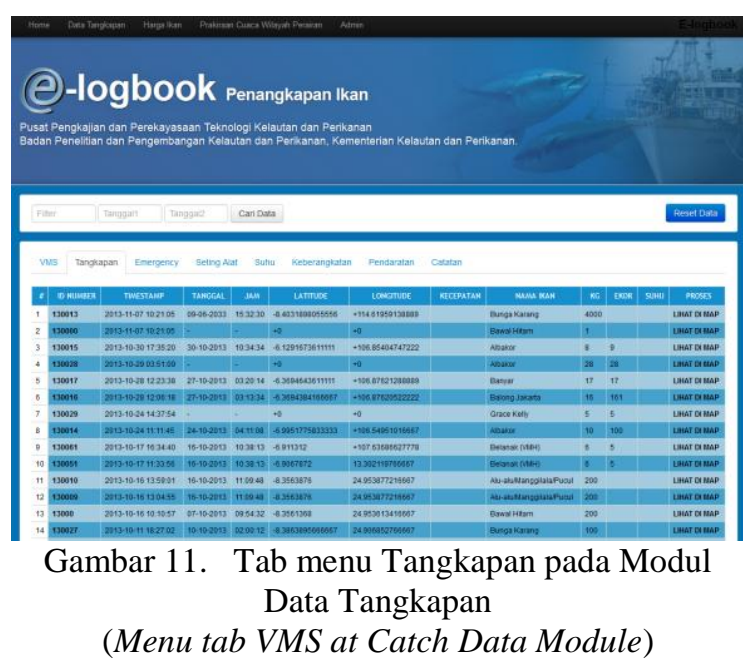

Gambar 12 menunjukkan tab menu Emergency pada modul data tangkapan. Data yang ditampilkan pada tab menu ini berasal dari fitur informasi keadaan darurat di atas kapal yang terdapat pada perangkat keras elektronik log book. Fitur informasi keadaan darurat tersebut terdiri dari: kebakaran, kebocoran, kecelakaan,

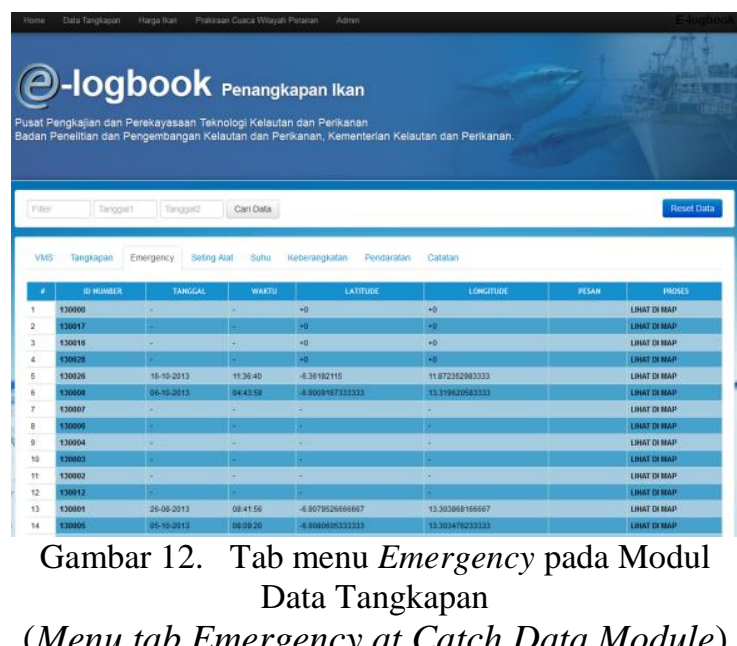

(Menu tab Emergency at Catch Data Module) 
pembajakan, mesin rusak, bahan bakar habis, ada kapal asing yang dicurigai, terjadi badai, tinggi ombak di atas 3 meter, ada kapal karam. Data ini akan ditampilkan jika nelayan melakukan pengisian informasi keadaan darurat pada elektronik log book. Data yang ditampilkan berisi waktu, koordinat, dan pesan keadaan darurat.

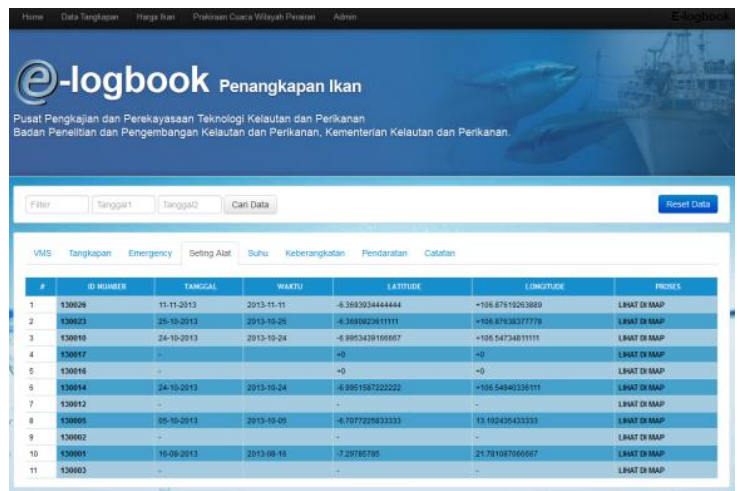

Gambar 13. Tab menu Seting Alat pada Modul Data Tangkapan

(Menu tab Setting Gear at Catch Data Module)

Gambar 13 menunjukkan tab menu Seting Alat pada modul data tangkapan. Data yang ditampilkan pada tab menu ini berasal dari pengisian data setting alat oleh nelayan pada elektronik $\log$ book. Data tersebut berisi waktu, koordinat, kode mulai dan akhir setting alat tangkap.

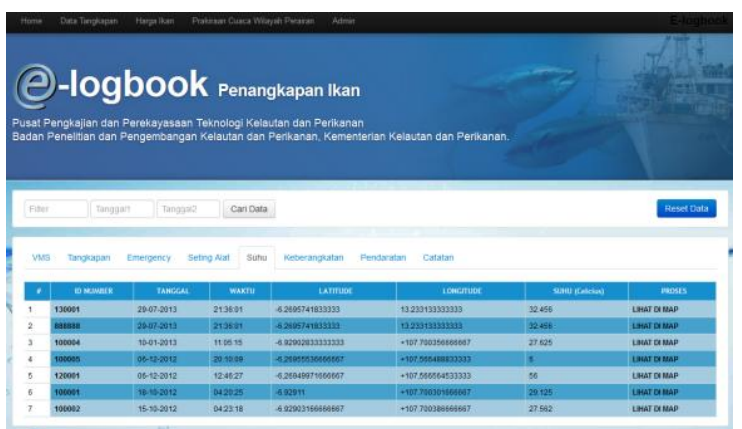

Gambar 14. Tab menu Suhu pada Modul Data Tangkapan

(Menu tab Temperature at Catch Data Module)

Gambar 14 menunjukkan tab menu Suhu pada modul data tangkapan. Data yang ditampilkan pada tab menu ini berasal dari pengukuran suhu dengan sensor suhu pada perangkat keras elektronik $\log$ book. Data tersebut berisi waktu, koordinat, dan suhu $\left({ }^{\circ} \mathrm{C}\right)$.

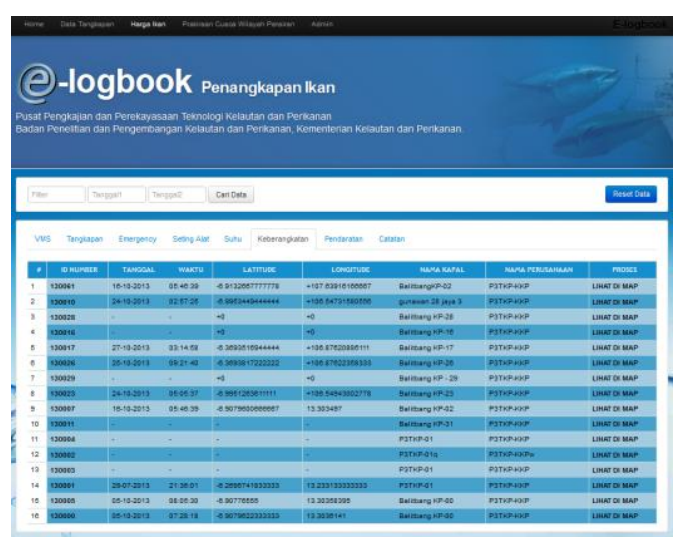

\section{Gambar 15. Tab menu Keberangkatan pada Modul Data Tangkapan \\ (Menu tab Departure at Catch Data Module)}

Gambar 15 menunjukkan tab menu Keberangkatan pada modul data tangkapan. Data yang ditampilkan pada tab menu ini berasal dari pengisian data kapal pada perangkat keras elektronik log book saat kapal akan berangkat dari pelabuhan untuk melakukan operasi penangkapan ikan. Data yang ditampilkan tersebut berisi waktu, koordinat, nama kapal, dan pelabuhan keberangkatan.

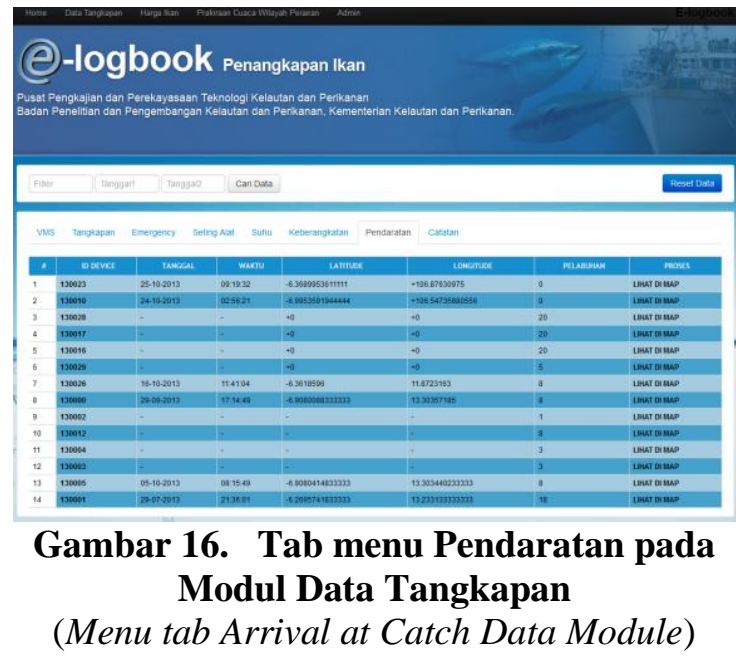

Gambar 16 menunjukkan tab menu Pendaratan pada modul data tangkapan. Data yang ditampilkan pada tab menu ini berasal dari pengisian data kapal pada perangkat keras elektronik $\log$ book saat kapal mendarat di pelabuhan setelah selesai melakukan operasi 
penangkapan ikan. Data yang ditampilkan tersebut berisi waktu, koordinat, dan pelabuhan pendaratan.

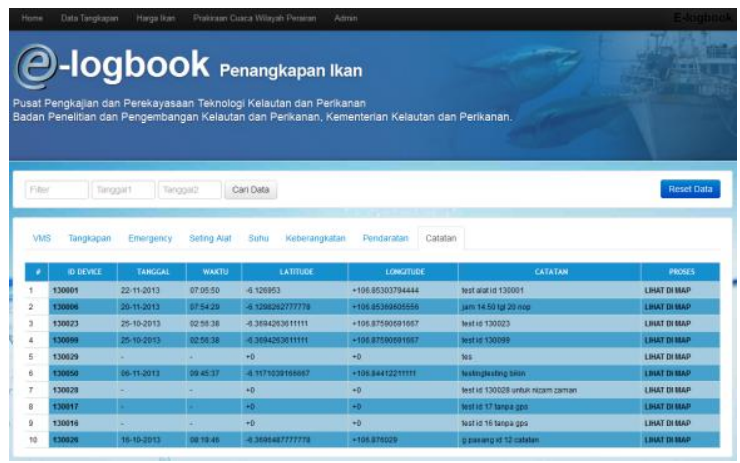

\section{Gambar 17 Tab menu Catatan pada Modul Data Tangkapan \\ (Menu tab Note at Catch Data Module)}

Gambar 17 menunjukkan tab menu Catatan pada modul data tangkapan. Data yang ditampilkan pada tab menu ini berasal dari pengisian data catatan oleh nelayan pada elektronik log book. Data catatan ini merupakan catatan hal-hal penting yang akan disampaikan ke pihak-pihak yang berwenang dan dapat digunakan sebagai tindak lanjut (Republik Indonesia, 2010).

\section{Modul Harga Ikan}

Modul ini memiliki fungsi untuk menampilkan produksi dan harga hasil tangkapan harian 5 jenis ikan dominan di pelabuhan perikanan. Untuk melihat harga tangkapan ikan pada suatu pelabuhan perikanan, bisa dilakukan dengan meng-klik link pelabuhan perikanan yang ada (Gambar 18 dan Gambar 19).

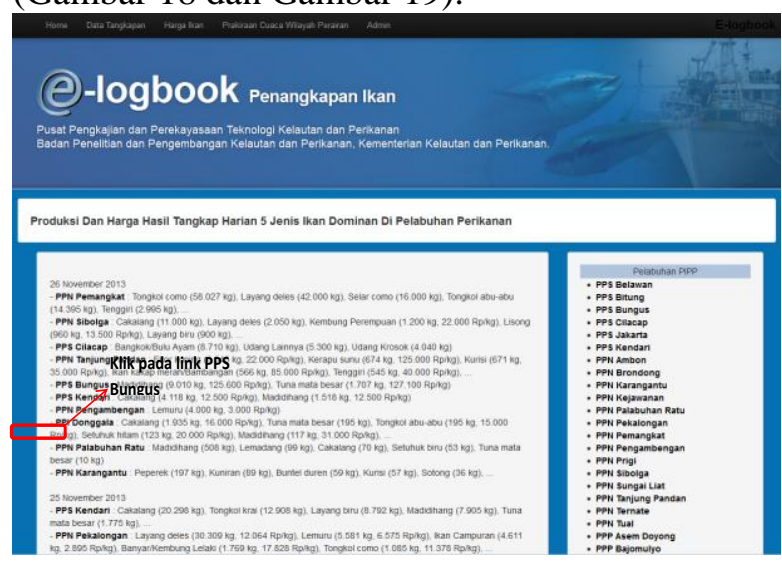

Gambar 18. Modul harga ikan

(Fish price module)

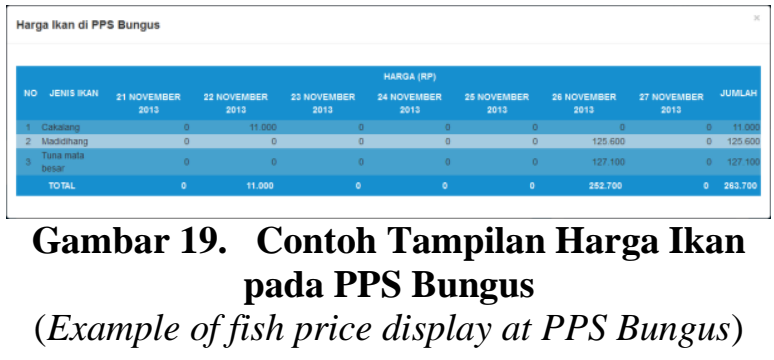

\section{Modul Prakiraan Cuaca}

Modul ini memiliki fungsi untuk menampilkan informasi prakiraan cuaca, ringkasan kondisi cuaca, dan peringatan cuaca buruk di wilayah perairan Indonesia. Untuk melihat detail prakiraan kondisi cuaca di perairan tertentu, pengguna dapat memilih dengan meng-klik drop down Pilih Wilayah Perairan, kemudian memilih perairan yang diinginkan, kemudian klik tombol Lihat. Untuk lebih detailnya lagi, perairan tersebut terbagi menjadi beberapa wilayah perairan, tiap detail wilayah tersebut dapat dilihat data prakiraan cuacanya dengan meng-klik link seperti pada Gambar 20, dan akan muncul window Detil seperti tampak pada Gambar 21.

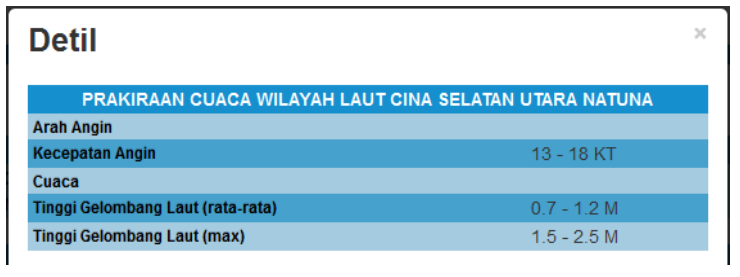

Gambar 20. Modul prakiraan cuaca (Weather forecast module) 


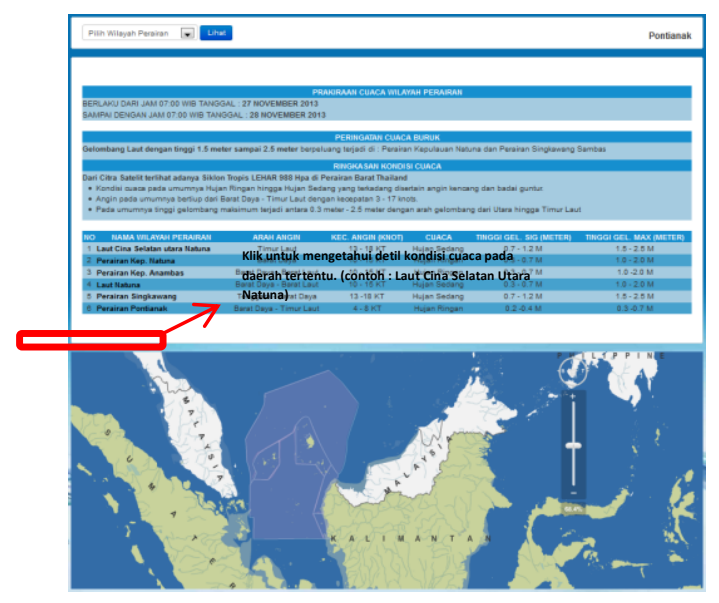

\section{Gambar 21. Detil prakiraan cuaca wilayah perairan tertentu \\ (Detail of weather forecast at certain sea area)}

Dari hasil implementasi tersebut, sistem informasi elektronik log book penangkapan ikan berbasis web dapat menampilkan data dari perangkat keras elektronik log book menjadi informasi statistik secara real time. Informasi tersebut tidak bisa diakses oleh umum, hanya dapat diakses pengguna dengan username dan password tertentu. Dengan demikian, kerahasiaan data elektronik log book dapat dijamin. Sistem informasi elektronik $\log$ book berbasis web ini akan memudahkan pemangku kebijakan, dalam hal ini adalah Direktorat Jenderal Perikanan Tangkap-KKP, dalam memantau data elektronik log book yang dipasang di kapal perikanan. Dengan pembangunan sistem informasi elektronik log book penangkapan ikan berbasis web ini, diharapkan dapat mendukung pemangku kebijakan dalam melakukan pengelolaan sumber daya perikanan yang berkelanjutan.

\section{KESIMPULAN DAN SARAN}

\section{Kesimpulan}

Telah dilakukan perancangan sistem informasi elektronik log book penangkapan ikan berbasis web dengan tahapan identifikasi kebutuhan sistem, perancangan perangkat lunak, dan implementasi sistem. Perancangan desain sistem database elektronik log book menggunakan MySQL. Desain sistem database tersebut berisi Conceptual Data Model (CDM) dan Physical Data Model (PDM). Untuk menggambarkan interaksi pengguna dengan sistem informasi elektronik log book dapat dilihat pada Data Flow Diagram (DFD). DFD pada perancangan sistem informasi elektronik log book terdiri dari DFD level-0, DFD level-1, dan DFD level-2. Modulmodul pada sistem informasi elektronik log book terdiri dari modul autentifikasi, modul data tangkapan, modul informasi harga ikan, dan modul informasi cuaca. Aplikasi kemudian diimplementasikan di domain www.p3tkpelogbook.net. Sistem informasi elektronik $\log$ book penangkapan ikan berbasis web yang sudah diaplikasikan pada tahun 2013 dapat memberikan informasi secara cepat dan tepat tentang data penangkapan ikan, informasi harga ikan, dan informasi cuaca perairan, dengan kerahasiaan data yang terjamin.

\section{Saran}

Diperlukan pengembangan fitur tentang regulasi penangkapan ikan di laut serta fasilitas komunikasi dua arah antara nelayan dengan petugas pelabuhan untuk kesempurnaan sistem informasi berbasis web ini.

\section{UCAPAN TERIMA KASIH}

Penulis mengucapkan terima kasih kepada Pusat Pengkajian dan Perekayasaan Teknologi Kelautan dan Perikanan (P3TKP), Balitbang KP yang telah memberikan kesempatan kepada kami untuk menggunakan sebagian data hasil penelitian Elektronik Log Book Penangkapan Ikan bagi penulisan makalah ini.

\section{DAFTAR PUSTAKA}

Exa, V. (2015). Pengertian Dan Contoh Data Flow Diagram (DFD). Diakses 24 Februari 2015 dari http://vebryexa.com/pengertian-dancontoh-data-flow-diagram-dfd.html.

Kuswardayan, I. (2004). Teknologi Database. Surabaya: Pendidikan Informatika dan Komputer Terapan-Institut Teknologi Sepuluh Nopember.

Marzuki, M. I. (2011). Membangun elektronik log book perikanan untuk menunjang pengelolaan sumber daya ikan yang berkelanjutan. Bunga Rampai: Application of Sustainable Development Technology in Indonesia. Jakarta: Pusat 
Pengkajian dan Perekayasaan Teknologi Kelautan dan Perikanan. Pp. 53-59.

Marzuki, M. I. dan Nugroho, H. (2013). Rancang bangun elektronik log book perikanan berbasis GPRS untuk mendukung pengelolaan perikanan berkelanjutan. Prosiding Seminar Hasil Penelitian Terbaik Tahun 2013. Jakarta: Badan Penelitian dan Pengembangan Kelautan dan Perikanan. Pp 164-179.

Nugroho, H., Sufyan, A., dan Akhwady, R. (2013). Integrasi Sistem Elektronik Log Book Penangkapan Ikan (ELPI) dengan Sistem Pemantauan Kapal Perikanan (VMS) untuk Pembangunan Perikanan Berkelanjutan. Jurnal Kelautan Nasional 8 (3), 101-110.

Nugroho, H. dan Sufyan, A. (2014). Pengembangan Perangkat Keras Elektronik Log Book Penangkapan Ikan Berbasis Layar Sentuh. Jurnal Kelautan Nasional 9 (1), 93-109.

Pratama, D. (2013). Pengertian dan Fungsi Data

Flow Diagram (DFD). Diakses 24

Februari 2015 dari

http://dhykapra.blogspot.com/2013/11/pen gertian-fungsidan-data-flowdiagram.html.

Republik Indonesia. (2009). Undang-Undang No. 45 Tahun 2009 tentang Perubahan Atas Undang-Undang No. 31 Tahun 2004 tentang Perikanan. Jakarta.

Republik Indonesia. (2010). Peraturan Menteri Kelautan dan Perikanan No. PER.18/MEN/2010 tentang Log Book Penangkapan Ikan. Jakarta.

Pohan, H.I. (1997). Pengantar Perancangan Sistem. Jakarta: Erlangga.

Setiawan, A.D.I. (2013). Sistem Informasi Berbasis Web. Diakses 19 Februari 2014 dari

http://myjavalamp.blogspot.com/2013/09/ sistem-informasi-berbasis-web-bagian1.html.

Soejarwo, P.A. dan Darmawan, A. (2011). Desain Sistem Manajemen Database Perawatan Kapal Inspeksi Perikanan. Jurnal Kelautan Nasional 6 (3), 169-178. 


\title{
PEDOMAN PENULISAN JURNAL KELAUTAN NASIONAL
}

JUDUL (Times New Roman, all caps, 12 pt, bold, centered)

TITLE (Times New Roman, all caps, 12 pt,italic, centered)

(kosong dua spasi tunggal, $12 \mathrm{pt}$ )

(Times New
Roman, $12 \mathrm{pt}$,

bold, centered)

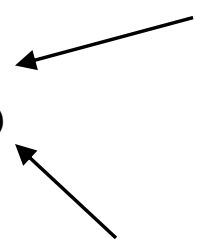

\section{Penulis Tunggal}

Nama Institusi

Alamat, nomor telepon dan faks

E-mail: penulis_tunggal@address.com

(kosong dua spasi tunggal, $12 \mathrm{pt}$ )

\section{Penulis Pertama $^{1}$, Penulis Kedua ${ }^{2}$ dan Penulis Ketiga \\ ${ }^{1}$ Nama Institusi \\ Alamat, nomor telepon dan faks \\ E-mail: penulis_pertama@address.com \\ (kosong satu spasi tunggal, $12 \mathrm{pt}$ )}

Diterima tanggal: ....., diterima setelah perbaikan: ....., disetujui tanggal: ........

(kosong satu spasi tunggal, $12 \mathrm{pt}$ )

\author{
ABSTRAK (12 pt, bold) \\ (kosong satu spasi tunggal, $12 \mathrm{pt}$ )
}

\begin{abstract}
Abstrak ditulis dalam bahasa Indonesia dan bahasa Inggris dengan jenis huruf Times New Roman, ukuran 10 pt, untuk bastrak bahasa Indonesia ditulis tegak, sedangkan abstrak bahasa inggris ditulis italic, spasi tunggal. Abstrak merupakan ringkasan yang utuh dan lengkap yang menggambarkan isi tulisan. Sebaiknya abstrak mencakup latar belakang, tujuan, metode, hasil, serta kesimpulan dari penelitian. Abstrak terdiri dari satu paragraf dengan jumlah kata paling banyak 250 kata dalam bahasa Indonesia dan 150 kata dalam bahasa Inggris.

(kosong satu spasi tunggal $10 \mathrm{pt}$ ).
\end{abstract}

Kata kunci: 3-5 kata kunci (Times New Roman, 10 pt)

(kosong satu spasi tunggal $10 \mathrm{pt}$ )

\section{ABSTRACT (12 pt, bold, italic) \\ (kosong satu spasi 12 pt)}

\begin{abstract}
Indonesian and English using Times New Roman font, size 10 pt, italic for English and normal for Indonesian, single spasing. Abstract is a full and complete summary that describe content of the paper It should contain background, objective, methods, results, and conclusion from the research. It consists of one paragraph and should be no more than 250 words in bahasa Indonesia and 150 words in English

(kosong satu spasi tunggal $10 \mathrm{pt}$ )
\end{abstract}

Keywords: 3-5 keywords (Times New Roman, 10 pt, italic)

(kosong dua spasi tunggal, $12 \mathrm{pt}$ )

PENDAHULUAN (12 pt, bold)

(kosong satu spasi tunggal, 11 pt)

Petunjuk penulisan ini disusun untuk keseragaman format penulisan dan kemudahan bagi penulis dalam proses penerbitan naskah di Jurnal Kelautan Nasional. Penulis bisa menggunakan bahasa Indonesia atau bahasa Inggris. Naskah dalam bahasa Indonesia harus sesuai dengan EYD yang 
berlaku, dan bila dalam bahasa Inggris sebaiknya memenuhi standard tata bahasa Inggris baku.

Penulis dapat mengirim artikel ilmiah ke alamat email: jurnalp3tkp@yahoo.com.

Naskah ditulis dalam format kertas berukuran A4 (210 mm x $297 \mathrm{~mm}$ ) dengan margin atas dan bawah masing-masing $3 \mathrm{~cm}$, margin kiri dan kanan masing-masing $2 \mathrm{~cm}$. Setiap paragraf ditulis dengan format justify. Jarak antara paragraf adalah satu spasi tunggal. Isi tulisan ditulis dengan jenis huruf Times New Roman, ukuran 11 pt. Panjang naskah minimal 6 halaman dan maksimal 15 halaman, termasuk lampiran.

Format naskah menggunakan aturan sebagai berikut:

a) Pada saat pengiriman awal, naskah ditulis dalam format 1 kolom.

b) Setelah naskah dinyatakan layak terbit, penulis harus merubah format naskah menjadi 2 kolom dengan jarak antar kolom $1 \mathrm{~cm}$.

Judul naskah harus mencerminkan inti dari isi suatu tulisan. Judul hendaknya menonjolkan fenomena (obyek) yang diteliti, bukan metode dan bukan kegiatan (proyek). Judul bersifat informatif, spesifik, efektif dan maksimal 15 kata. Jika naskah dalam bahasa Indonesia, ditulis terlebih dahulu judul bahasa Indonesia kemudian diikuti judul dalam bahasa Inggris. Sebaliknya, jika naskah dalam bahasa Inggris, ditulis dahulu judul bahasa Inggris kemudian diikuti judul dalam bahasa Indonesia.

Nama penulis ditulis secara lengkap di bawah judul tanpa menyebutkan gelar. Di bawahnya, dicantumkan nama lembaga dan alamat lengkap tempat penulis bekerja beserta alamat e-mail penulis pertama untuk korespondensi. Jika penulis lebih dari satu orang dan bekerja di lembaga yang sama, maka pencantuman satu alamat telah dianggap cukup mewakili alamat penulis lainnya.

Keterangan naskah ditulis setelah identitas penulis. Ditulis miring dengan jenis huruf jenis huruf Times New Roman, ukuran 9 pt.

Abstrak ditulis dalam bahasa Indonesia dan bahasa Inggris yang masing - masing dilengkapi dengan kata kunci (keywords). Kata kunci dapat berupa kata tunggal atau kata majemuk (terdiri lebih dari satu kata). Penulisan kata kunci antara tiga sampai lima $(3-5)$ kata dan dapat mengikuti klasifikasi sebagai berikut: metode teoritis, metode eksperimen, fenomena, obyek penelitian dan aplikasinya.

Naskah disusun dalam 4 subjudul yaitu: Pendahuluan, Bahan dan Metode, Hasil dan Pembahasan, Kesimpulan dan Saran, Daftar Pustaka, dan Lampiran (jika ada). Subjudul ditulis dengan huruf besar cetak tebal dan tidak diberi nomor. Subjudul untuk naskah bahasa Inggris sebagai berikut: Introduction, Tools and Methods, Results and Discussion, Conclusions and Suggestion, References dan Appendix (jika ada). Penggunaan subsubjudul sebaiknya dihindari, apabila diperlukan diberi nomor bertingkat dengan angka latin seperti contoh berikut: 1., 1.1. 1.2., ... dan seterusnya.

Pendahuluan hendaklah mencakup hal-hal berikut ini: latar belakang, perumusan masalah, tujuan, teori, dan hipotesis (jika ada). Untuk penemuanpenemuan ilmiah yang telah dipublikasikan sebelumnya baik oleh diri-sendiri maupun orang lain dan berkaitan dengan penelitian yang dikerjakan, bisa dimasukkan di dalam subjudul pendahuluan ini.

Metode penelitian yang digunakan harus ditulis sesuai dengan cara ilmiah, yaitu rasional, empiris dan sistematis. Seyogyanya disebutkan waktu dan tempat penelitian secara jelas, berikut data maupun alat dan bahan yang dipakai dalam penelitian.

Hasil dan pembahasan berisi hasil analisis fenomena di wilayah penelitian yang relevan dengan tema kajian. Hasil penelitian hendaknya dibandingkan dengan teori dan temuan penelitian yang relevan

Kesimpulan bisa berupa kesimpulan khusus dan kesimpulan umum. Kesimpulan khusus merupakan hasil analisa data atau hasil uji hipotesa tentang fenomena yang diteliti. Kesimpulan umum sebagai hasil generalisasi atau keterkaitan dengan fenomena serupa di wilayah lain dari publikasi terdahulu. Hal yang perlu diperhatikan adalah segitiga konsistensi (masalah-tujuan-kesimpulan harus konsisten).

Penggunaan catatan kaki tidak diperkenankan. Simbol/lambang ditulis dengan jelas dan konsisten. 
Istilah asing ditulis dengan huruf italic. Singkatan harus dituliskan secara lengkap pada saat disebutkan pertama kali, setelah itu bisa ditulis kata singkatnya.

Tabel ditulis dengan Times New Roman ukuran 10 pt dan berjarak satu spasi dibawah judul tabel. Judul tabel ditulis dengan bahasa Indonesia dan terjemahan bahasa Inggris di bawahnya. Judul tabel ditulis dengan huruf berukuran $10 \mathrm{pt}$ dan ditempatkan diatas tabel. Penomoran tabel menggunakan angka Latin $(1,2, \ldots .$.$) . Tabel$ diletakkan segera setelah disebutkan di dalam naskah. Tabel diletakkan pada posisi paling atas atau paling bawah dari setiap halaman dan tidak diapit oleh kalimat. Apabila tabel memiliki lajur/kolom cukup banyak, bisa digunakan format satu kolom atau satu halaman penuh. Setiap tabel harus mencantumkan sumber.

(kosong satu spasi tunggal, 11 pt)

Tabel 1. Kriteria umum stabilitas kapal ikan .

Table 1. Common criteria fishing vessel stability

\begin{tabular}{ll}
\hline \multicolumn{1}{c}{ Kriteria } & Nilai Kriteria IMO \\
\hline $0^{0}-30^{0}$ & $\geq 3,151 \mathrm{~m} \cdot \mathrm{deg}$ \\
$0^{0}-40^{0}$ & $\geq 5,157 \mathrm{~m} \cdot \mathrm{deg}$ \\
$30^{\circ}-40^{\circ}$ & $\geq 1,719 \mathrm{~m} . \mathrm{deg}$ \\
$\mathrm{GZ}_{\text {max }}$ pada sudut $30^{\circ}$ atau lebih & $\geq 0,2 \mathrm{~m}$ \\
sudut $\mathrm{GZ}$ & $\geq 25 \mathrm{deg}$ \\
$\mathrm{GM}_{0}$ & $\geq 0,150 \mathrm{~m}$ \\
\hline
\end{tabular}

Sumber: IMO, 2002

(kosong satu spasi tunggal, 11 pt)

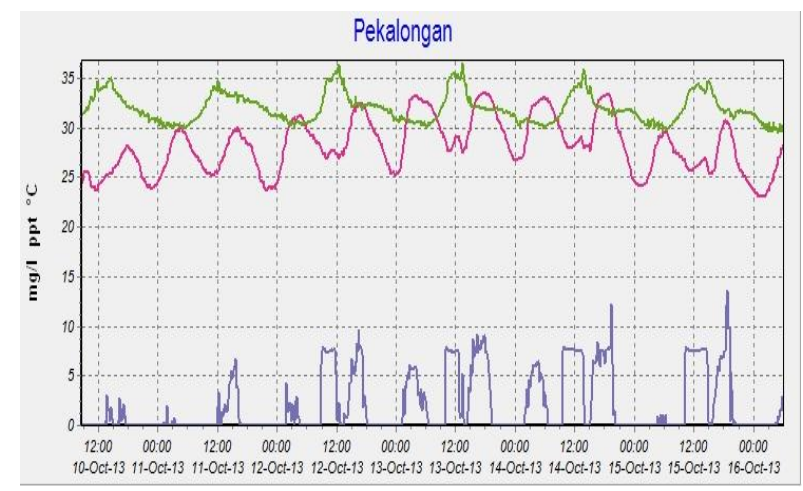

Gambar 1. Parameter DO (warna biru), parameter salinitas (warna jingga), parameter suhu (warna hijau) dari telemetri buoy PLUTO.

Figure 1. DO parameter (blue color), salinity parameter (violet color), temperature parameter (green color) from buoy PLUTO's telemetry. Sumber: Hasil pengukuran

(kosong satu spasi tunggal, 11 pt)
Gambar diletakkan segera setelah disebutkan dalam naskah. Gambar diletakkan pada posisi paling atas atau paling bawah dari setiap halaman dan tidak boleh diapit kalimat. Gambar diletakkan simetris dalam kolom. Apabila gambar cukup besar, bisa digunakan format satu kolom. Penomoran gambar menggunakan angka latin. Penulisan judul gambar menggunakan huruf Times New Roman berukuran 10 pt dan diletakkan di bagian bawah, seperti pada contoh diatas. Judul gambar ditulis dengan bahasa Indonesia dan terjemahan bahasa Inggris di bawahnya dalam tanda kurung dan cetak miring. Setiap gambar harus menyebutkan sumbernya. Jika gambar yang ditampilkan merupakan milik pribadi, maka ditulis "Sumber: Dokumentasi pribadi"

Apabila terdapat persamaan reaksi atau matematis, diletakkan simetris pada kolom. Nomor persamaan diletakkan di ujung kanan dalam tanda kurung, dan penomoran dilakukan secara berurutan. Apabila terdapat rangkaian persamaan yang lebih dari satu baris, maka penulisan nomor diletakkan pada baris terakhir. Penunjukkan persamaan dalam naskah dalam bentuk singkatan, seperti Pers. (1).

(kosong satu spasi tunggal 11 pt)

$$
k a=-\left(\frac{\partial u}{\partial x}+\frac{\partial v}{\partial y}\right)
$$

(kosong satu spasi tunggal 11 pt)

Penurunan persamaan matematis tidak perlu ditulis semuanya secara detail, hanya dituliskan bagian yang terpenting, metode yang digunakan dan hasil akhirnya.

Pengutipan/sitasi pustaka di dalam naskah mengacu pada pedoman sebagai berikut:

- Kutipan atau keterangan yang bersumber dari naskah yang ditulis oleh penulis tunggal, sitasinya ditulis dengan menyebutkan nama belakang penulis diikuti dengan tahun penerbitan naskah. Contoh: Walker (2007) atau (Walker, 2007).

- Kutipan atau keterangan yang bersumber dari naskah yang ditulis oleh 2-5 penulis, pada sitasi awal ditulis dengan menyebutkan semua nama belakang penulis diikuti dengan tahun penerbitan naskah. Sedangkan sitasi selanjutnya, cukup ditulis nama penulis 
pertama diikuti dengan et al dan tahun penerbitan naskah. Contoh:

- Sitasi awal: Walker, Allen, Bradley, Ramirez dan Soo (2008) atau (Walker, Allen, Bradley, Ramirez dan Soo, 2008).

- Sitasi selanjutnya: Walker et al. (2008) atau (Walker et al., 2008).

- Kutipan atau keterangan yang bersumber dari naskah yang ditulis oleh 6 penulis atau lebih, sitasinya ditulis dengan menyebutkan nama belakang penulis pertama diikuti dengan et al dan tahun penerbitan naskah. Contoh: Wasserstein et al. (2005) atau (Wasserstein et al., 2005)

- Kutipan atau keterangan yang bersumber dari naskah yang ditulis oleh institusi, lembaga atau grup yang memiliki singkatan, pada sitasi awal ditulis dengan menyebutkan nama lengkap institusi, lembaga atau grup diikuti dengan tahun penerbitan naskah. Sedangkan sitasi selanjutnya, cukup ditulis dengan singkatannya diikuti dengan tahun penerbitan naskah. Contoh:

- Sitasi awal: Kementerian Kelautan dan Perikanan (2010) atau (Kementerian Kelautan dan Perikanan, 2010).

- Sitasi selanjutnya: KKP (2010) atau (KKP, 2010).

- Kutipan atau keterangan yang bersumber dari naskah yang ditulis oleh institusi, lembaga atau grup yang tidak memiliki singkatan, sitasinya ditulis dengan menyebutkan nama institusi, lembaga atau grup diikuti dengan tahun penerbitan naskah. Contoh: University of Pittsburgh (2005) atau (University of Pittsburgh, 2007).

Teknik sitasi tersebut dapat dilihat perbedaannya melalui tabel di bawah ini.

Teknik sitasi di dalam teks

\begin{tabular}{|c|c|c|c|c|}
\hline Type of citation & First citation in text & $\begin{array}{l}\text { Subsequent } \\
\text { citations in text }\end{array}$ & $\begin{array}{l}\text { Parenthetical format, first } \\
\text { citation in text }\end{array}$ & $\begin{array}{l}\text { Parenthetical format, } \\
\text { subsequent citations in text }\end{array}$ \\
\hline One work by one author & Walker (2007) & Walker (2007) & (Walker, 2007) & (Walker, 2007) \\
\hline One work by two authors & Walker and Allen (2004) & Walker and Allen (2004) & (Walker \& Allen, 2004) & (Walker \& Allen, 2004) \\
\hline $\begin{array}{l}\text { One work by three } \\
\text { authors }\end{array}$ & $\begin{array}{l}\text { Bradley, Ramirez, and Soo } \\
\text { (1999) }\end{array}$ & Bradley et al. (1999) & (Bradley, Ramirez, \& Soo, 1999) & (Bradley et al., 1999) \\
\hline One work by four authors & $\begin{array}{l}\text { Bradley, Ramirez, Soo, and } \\
\text { Walsh (2006) }\end{array}$ & Bradley et al. (2006) & $\begin{array}{l}\text { (Bradley, Ramirez, Soo, \& } \\
\text { Walsh, 2006) }\end{array}$ & (Bradley et al., 2006) \\
\hline One work by five authors & $\begin{array}{l}\text { Walker, Allen, Bradley, } \\
\text { Ramirez, and Soo (2008) }\end{array}$ & Walker et al. (2008) & $\begin{array}{l}\text { (Walker, Allen, Bradley, } \\
\text { Ramirez, \& Soo, 2008) }\end{array}$ & (Walker et al., 2008) \\
\hline $\begin{array}{l}\text { One work by six or more } \\
\text { authors }\end{array}$ & Wasserstein et al. (2005) & $\begin{array}{l}\text { Wasserstein et al. } \\
(2005)\end{array}$ & (Wasserstein et al., 2005) & (Wasserstein et al., 2005) \\
\hline $\begin{array}{l}\text { Groups (readily identified } \\
\text { through abbreviation) as } \\
\text { authors }\end{array}$ & $\begin{array}{l}\text { National Institute of Mental } \\
\text { Health (NIMH, 2003) }\end{array}$ & $\mathrm{NIMH}(2003)$ & $\begin{array}{l}\text { (National Institute of Mental } \\
\text { Health [NIMH], 2003) }\end{array}$ & (NIMH, 2003) \\
\hline $\begin{array}{l}\text { Groups (no abbreviation) } \\
\text { as authors }\end{array}$ & University of Pittsburgh (2005) & $\begin{array}{l}\text { University of Pittsburgh } \\
(2005)\end{array}$ & (University of Pittsburgh, 2005) & (University of Pittsburgh, 2005) \\
\hline
\end{tabular}

\section{DAFTAR PUSTAKA}

(kosong satu spasi tunggal, 11 pt)

Penulisan daftar pustaka sesuai dengan urutan pengutipannya dalam naskah. Jumlah sumber acuan dalam satu tulisan paling sedikit 15 (lima belas) sumber acuan, dengan $80 \%$ merupakan sumber acuan primer dan $80 \%$ merupakan terbitan 5 tahun terakhir. Sumber acuan primer adalah sumber acuan yang langsung merujuk pada bidang ilmiah tertentu, sesuai topik penelitian dan sudah teruji. Sumber acuan primer dapat berupa: tulisan dalam makalah ilmiah dalam jurnal internasional maupun nasional terakreditasi, hasil penelitian di dalam disertasi, tesis, maupun skripsi. Buku (textbook), termasuk dalam sumber acuan sekunder.

Daftar pustaka disusun menurut abjad, tanpa menggunakan nomor urut, dengan ukuran font 10 . Penulisan setiap acuan, menjorok (indent) $1 \mathrm{~cm}$ mulai baris kedua. 
Gaya penulisan daftar pustaka mengacu pada $A P A$ style yang dikembangkan oleh American Psychological Association, seperti contoh berikut ini:

\section{Paper dalam jurnal}

a. Artikel dalam jurnal (1 penulis)

Handayani, A. S. (2010). Analisis daerah endemik bencana akibat cuaca ekstrim di Sumatera Utara, Jurnal Meteorologi dan Geofisika, $11(1), 52-57$.

b. Artikel dalam jurnal (2 -6 penulis)

Suryanto, W., Nurdiyanto, B., \& Pakpahan, S. (2010). Implementasi perhitungan receiver function untuk gempa jauh menggunakan Matlab. Jurnal Meteorologi dan Geofisika, 11(1), 66-72.

c. Artikel dalam jurnal (lebih dari 6 penulis)

Subagyono, K., Sugiharto, B., Purwani, E. T., Susilokarti, D., Las, I., Unadi, A., et. al. (2010). Technology needs assessment (TNA) for climate change mitigation in agriculture sector: criteria, prioritizing and barriers. Jurnal Meteorologi dan Geofisika, 11(2), 96105.

\section{Buku}

a. Buku (1 penulis)

Shearer, P. M. (1999). Introduction to seismology. Cambridge: Cambridge University Press.

b. Buku (2-6 penulis)

Trewartha, G. T., \& Horn, L. H. (1980). An introduction to climate. New York: McGraw-Hill.

c. Buku (lebih dari 6 penulis)

Johnson, L., Lewis, K., Peters, M., Harris, Y., Moreton, G.,...Morgan, B. (2005). How far is far? London: McMillan.

d. Buku tanpa penulis

Art Students International. (1988). Princeton, NJ: Educational Publications International.

e. Buku tanpa bab

Skinner, B. F. (1969). Contingencies of reinforcement. New York: AppletonCentury- Crofts.

Bremner, G., \& Fogel, A. (Eds.). (2001). Blackwell handbook of infant development. Malden, MA: Blackwell.

f. Buku dengan bab

Harlow, H. F. (1958). Biological and biochemical basis of behavior. In D. C. Spencer (Ed.), Symposium on interdisciplinary research (pp. 239-252). Madison: University of Wisconsin Press.

g. Buku dengan edisi/versi

Strunk, W., Jr., \& White, E. B. (1979). The elements of style (3rd ed.). New York: Macmillan.
Cohen, J. (1977). Manual labor and dream analysis (Rev. ed.). New York: Paradise Press.

American Psychiatric Association. (1994). Diagnostic and statistical manual of mental disorders (4th Ed.). Washington, DC: Author.

h. Buku terjemahan

Nybakken, J. W. (1988). Biologi laut: Suatu pendekatan ekologis. Terj. dari Marine biology: An ecological approach (Eidman, M., Koesoebiono, D. G. Bengen, M. Hutomo \& S. Sukardjo, Penerjemah). Jakarta: PT. Gramedia.

i. Buku dengan beberapa volume

Wilson, J. G., \& Fraser, F. (Eds.). (1988-1990). Handbook of wizards (Vols. 1-4). New York: Plenum Press.

j. Artikel atau bab dalam buku

Fremerey, M. (2006). Resistance to change in higher education: Threat or opportunity? In M. Fremerey, \& M. Pletsch-Betancourt. (Eds.) Prospects of change in higher education: Towards new qualities \& relevance. Frankfurt: IKO-Vlg fur Interkult, GW/Transaction Pubs.

Jahr, V., \& Teichler, U. (2002). Employment and work of former mobile students. In U. Teichler (Ed.) ERASMUS in the SOCRATES programme, finding of an evaluation study (pp. 117-135). Bonn: Lemmens.

\section{Prosiding}

Meilano, I., Abidin, H. Z., \& Natawidjaya, D. H. (2009). Using $1-\mathrm{Hz}$ GPS data to measure deformation caused by Bengkulu earthquake. Proceeding of International Symposium on Earthquake and Precursor, 153-158. Bukittinggi: Research and Development Center, BMKG.

\section{Makalah seminar, lokakarya}

Ibnu, S. (2011). Isi dan format jurnal ilmiah. Makalah disajikan dalam Lokakarya Nasional Pengelolaan dan Penyuntingan Jurnal Ilmiah, Malang: Universitas Negeri Malang.

\section{Skripsi, disertasi, tesis}

Riyadi, M. (1996). Pemodelan gaya berat tiga dinensi untuk melokalisir jebakan timah di daerah Pemali-Bangka. Tesis. Fakultas MIPA: Universitas Indonesia.

\section{Laporan penelitian}

Sumaryanto. (2008). Karakteristik sosial ekonomi petani pada berbagai agroekosistem. Laporan penelitian, Pusat Analisis Ekonomi dan Kebijakan Pertanian. Bogor: Kementrian Pertanian. 


\section{Sumber digital}

a. Buku elektonik dari perpustakan digital

Wharton, E. (1996). The age of innocence. Charlottesville, VA: University of Virginia Library. Diakses 6 Maret 2001, dari netLibrary database.

b. Artikel Jurnal dari perpustakaan digital

Schraw, G., \& Graham, T. (1997). Helping gifted students develop metacognitive awareness. Roeper Review, 20, 4-8. Diakses 4 November 1998, dari Expanded Academic ASAP database.

c. Artikel Majalah atau Koran dari Internet (bukan dari perpustakaan digital)

Sarewitz, D., \& Pielke, R. (2000, July). Breaking the global warming gridlock [Electronic version]. The Atlantic Monthly, 286(1), 5464.

d. Artikel e-Journal

Bilton, P. (2000, January). Another island, another story: A source for Shakespeare's The Tempest. Renaissance Forum, 5(1). Diakses 28 Agustus 2001, dari http://www.hull.ac.uk/renforum/current.html

e. Halaman Web

Shackelford, W. (2000). The six stages of cultural competence. In Diversity central: Learning. Diakses 16 April 2000, dari http://www.diversityhotwire.com/learning/c ultural_insights.html

f. Web Site dari organisasi

American Psychological Association. (n.d.) APAStyle.org: Electronic references. Diakses 31 Agustus 2001, dari http://www.apa.org/journals/webref.html 